\title{
Policies for control of communicable disease in day
} care centres

\author{
A Chouillet, $\mathrm{H}$ Maguire, Z Kurtz
}

\begin{abstract}
A survey was carried out to identify the availability and quality of guidelines for the prevention and control of communicable disease and procedures in use in child day care centres within the South West Thames Regional Health Authority.

A sample of 50 day care centres was investigated including those funded by social services and privately funded day care centres. Policies for the prevention and control of communicable disease for children and staff showed a wide variation between different centres. Exclusion criteria were unclear especially in relation to carriers of the hepatitis $B$ virus and HIV positive children. Channels for reporting and seeking advice were inconsistent. It is recommended that clear and up to date written guidelines on the prevention and control of communicable diseases should be available in all day care centres with clear indications of good practice and channels for reporting and advice. It is desirable that guidelines are agreed by the different health and local authorities throughout the region.
\end{abstract}

\section{(Arch Dis Child 1992;67:1103-6)}

The number of child day care centres in the United Kingdom has been growing steadily and is expected to increase further in the future. ${ }^{12}$ Care is provided on a regular paid basis for children under the age of 5 years in various settings outside the child's home such as nurseries, play groups, or nursery schools which are registered with local authority social services departments. Growth has been particularly great in the private sector, increasing from 1093 nurseries (28 972 places) in 1986 to 1781 nurseries (46 938 places) in 1989.

Children attending day care centres have been shown to be at increased risk of infection, in particular from diarrhoeal conditions, otitis media, varicella, hepatitis $A$ and invasive Haemophilus influenzae type $\mathrm{b}$ disease. ${ }^{3-6}$ In addition there is a potential for transmission to parents and care providers of other infections such as rubella and cytomegalovirus, ${ }^{7}$ with possible risks for the fetus in susceptible pregnant contacts. Concern has arisen about the possibility of spread of two blood borne organisms in the child day care setting: hepatitis $B$ virus and HIV. 8-10

Day care provides a much needed service for children and families of whom a significant proportion is at high risk of health problems. ${ }^{11}$ It is important that staff know how to minimise health hazards for the children in their care and for themselves. In the past year an outbreak of shigellosis and of cryptosporidiosis occurred in nurseries in the South West Thames region which has a population of approximately 170000 children aged under 5 years. On investigation a general lack of knowledge of procedures for the prevention and control of communicable diseases was found. The study reported here was undertaken to assess the availability and quality of information in the form of policy or guidelines, or both, in day care centres in the region and their use.

\section{Methods}

A sample of 50 day care centres was taken from those registered with each of the eight local authorities in the region. Drop in centres, parent-toddler groups, nursery schools, and childminders were excluded. All 20 centres funded by the social services and a random sample of the 352 privately run centres were included with representative numbers from each local authority.

Information was obtained by a questionnaire sent to the director of each day care centre and included: numbers of children attending and their sociodemographic characteristics; any requirement for immunisation before entry; whether the centre gave advice or more actively promoted immunisation, or both; from where advice about infectious diseases was obtained; episodes and reporting of infections over the previous year; policies for excluding children because of communicable disease; hygiene and food preparation practices; and pre-employment health screening of staff.

All the local authorities, each of the 13 district health authorities in the region, and each day care centre selected for study were asked if they used any written guidelines about communicable disease control and to forward copies.

Interviews were carried out with directors of three day care centres to validate and explore in depth the findings of the questionnaire survey.

\section{Results}

Completed questionnaires were received from 37 day care centres, an overall response rate of $74 \%$. Fifteen questionnaires were returned by the 20 sampled day care centres funded by social services and 22 by the 30 private centres.

The number of children (1324) attending the 37 centres sampled represented $66 \%$ of the total 927 places in social services and $9 \%$ of those (total 7927 places) in privately run day care 
centres in the region. Ninety four per cent of the children were aged 2 years or over, $5 \%$ (62 children) were aged between 1 and 2 years, and 12 children were aged less than 1 year.

Most day care centres (73\%) had places for between 20 and 40 children; $18 \%$ of centres catered for less than 20 children, and nearly $9 \%$ for more than $\mathbf{4 0 .}$

Day care centres funded by social services gave priority to children with 'special needs'. Overall $15 \%$ of children were categorised in this way with about two thirds of these reported to have 'social' needs, including ill, single, or unsupported parents, or risk of abuse. Other children had learning difficulties, language delay, developmental and behavioural problems, physical impairments such as cerebral palsy, or sensory deficit, but only children with mild mental handicap were said to be accepted. Only three children with special needs were attending the privately run day care centres.

\section{GUIDELINES}

Guidelines specifically for communicable disease control were available to day care centres from six of the eight social services departments but were not provided routinely to privately funded centres. These different social services guidelines had been produced between 1984 and 1991 and often gave incomplete or out of date information. One set of guidelines related only to HIV infection; others lacked information about good practice with regard to immunisation, exclusion criteria for children with infection, or gave no indication about how or when to report infectious disease. All the guidelines provided a telephone number for making inquiries which was invariably that of the local environmental health department but was not always correct. A set of guidelines had recently been drawn up by two district health authorities with the collaboration of consultants in communicable

Table 1 Policies for communicable disease prevention and control in day care centres

\begin{tabular}{lll}
\hline Policy & \multicolumn{2}{l}{ Day care centres } \\
\cline { 2 - 3 } & $\begin{array}{l}\text { Social services } \\
(n=15)\end{array}$ & $\begin{array}{c}\text { Private } \\
(n=22)\end{array}$ \\
\hline Had written policy for infection control & 13 & 17 \\
Had written hygiene policy & 14 & 18 \\
Recorded medical history of children & 15 & 19 \\
Recorded past infectious disease in children & 14 & 16 \\
Recorded immunisation history of children & 15 & 13 \\
Recommended parents to update immunisation & 13 & 1 \\
Arranged for immunisation & 7 & 3 \\
Gave immunisation on site & 7 & 7 \\
Had written guidelines on exclusion criteria & 8 & 6 \\
Would exclude children carrying the hepatitis B virus & 4 & 4 \\
Would exclude HIV positive children & 1 & \\
\hline
\end{tabular}

Table 2 Pre-employment staff screening policies for communicable disease prevention and control in day care centres

\begin{tabular}{llc}
\hline Policy & Day care centres & \\
\cline { 2 - 3 } & $\begin{array}{l}\text { Social services } \\
(n=15)\end{array}$ & $\begin{array}{l}\text { Private } \\
(n=22)\end{array}$ \\
\hline Used pre-employment questionnaire & 15 & 13 \\
Tuberculin skin testing & 8 & 6 \\
Recommended rubella immunisation (female staff) & 5 & 6 \\
\hline
\end{tabular}

disease control, community paediatricians, and the local authorites. These were comprehensive and up to date and included signs and symptoms for the most common infectious diseases, criteria for reporting and exclusion, and information about HIV and hepatitis B, recommended immunisations, general hygiene, and first aid. The necessary measures for protection for staff from rubella and screening for tuberculosis were outlined.

Table 1 summarises the content of policies reported to be used within the day care centres. Hygiene policies were used in nearly all social services centres. Their own guidelines for hygiene had been produced by 10 of the private centres but three said they used 'common sense'. Children's immunisation status was not recorded routinely nor recommendations made for those children found not to be fully protected. Ailmost half the social services but few private centres arranged to take children to be immunised or provided immunisation on site. Criteria for the exclusion of children varied and 22 of the centres did not have written guildelines for these. It was clear that in many instances parents were offered conflicting advice from day care centres and general practitioners. Five centres said they would not accept a child who was HIV positive, though none had actually been faced with the problem. Several private centres were not sure what they would do in such an instance nor where to ask for expert advice. Nearly a third of the centres reported that children known to be carrying the hepatitis $B$ virus would be excluded and one centre, having excluded a child for this reason, asked for further advice on the study questionnaire form.

Table 2 summarises the policies for staff health. Pre-employment questionnaires were used in all social services day care centres and in over half of those in the private sector. Preemployment tuberculin skin testing was carried out in less than half of the centres. A third of the centres made recommendations to their female staff about rubella immunisation but there were no specific recommendations for pregnant staff unless a case of rubella occurred at a centre. One centre offered hepatitis B immunisation to all its staff.

Table 3 summarises how the day care centres reported infectious disease and sought advice. These procedures were found to be extremely irregular. Three quarters of the centres had no set pattern for seeking advice but used a variety of sources of help. Private centres usually contacted a general practitioner or health visitor, or both, for advice. Social services centres also contacted a health visitor but were more likely to contact an environmental health officer, a community paediatrician, or consultant in communicable disease control. There was felt to be no clear need to report an occurrence if a disease was not on the list of notifiable diseases, as for diarrhoea, and there was general uncertainly about the circumstances in which reporting is advisable.

Table 4 shows the infections reported to have occurred during the previous year. Chickenpox, diarrhoea, and ear infections were common, with 
Table 3 Advice and reporting for communicable disease in day care centres

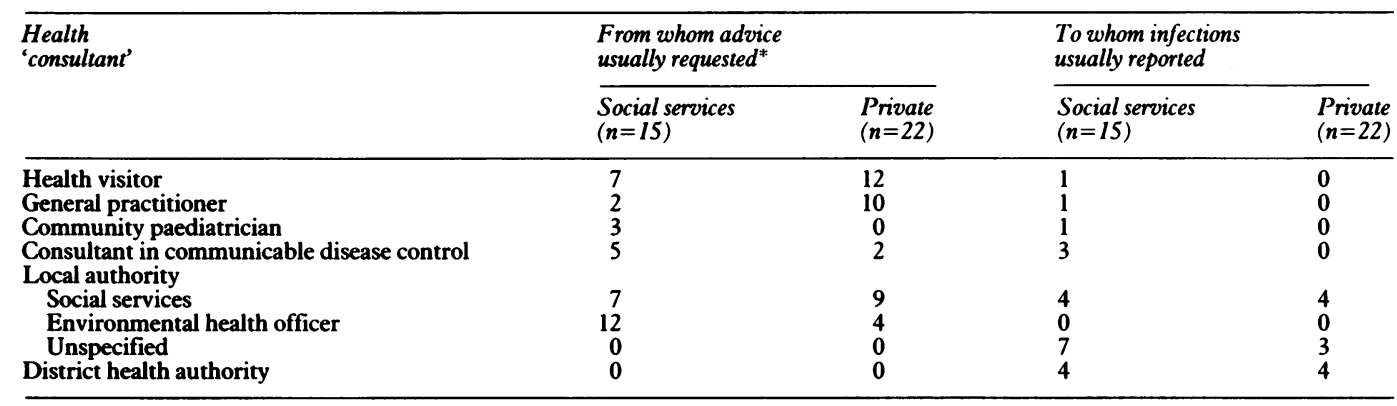

${ }^{*}$ Several advisors may be contacted by each centre.

Table 4 Infections reported by day care centres (DCCs) during 1990-1

\begin{tabular}{|c|c|c|c|c|}
\hline \multirow[t]{2}{*}{$\begin{array}{l}\text { Type of } \\
\text { infection }\end{array}$} & \multirow{2}{*}{$\begin{array}{l}\text { No of DCCs } \\
\text { reporting } \\
\text { episodes or cases } \\
(n=37)\end{array}$} & \multirow{2}{*}{$\begin{array}{l}\text { No of DCCs } \\
\text { specifying } \\
\text { number affected }\end{array}$} & \multicolumn{2}{|c|}{$\begin{array}{l}\text { Estimated No } \\
\text { affected }\end{array}$} \\
\hline & & & Children & Staff \\
\hline $\begin{array}{l}\text { Measles } \\
\text { Mumps } \\
\text { Rubella } \\
\text { Whooping cough } \\
\text { Meningitis } \\
\text { Chickenpox } \\
\text { Diarrhoea } \\
\text { Dysentery (shigella) } \\
\text { Cryptosporidiosis } \\
\text { Food poisoning } \\
\text { Ear infections } \\
\text { Skin infections } \\
\text { Glandular fever } \\
\text { Hand/foot/mouth diseases }\end{array}$ & $\begin{array}{r}14 \\
7 \\
7 \\
3 \\
2 \\
33 \\
26 \\
1 \\
1 \\
2 \\
23 \\
6 \\
3 \\
2\end{array}$ & $\begin{array}{r}9 \\
6 \\
6 \\
3 \\
2 \\
27 \\
16 \\
1 \\
1 \\
1 \\
17 \\
4 \\
1 \\
2\end{array}$ & $\begin{array}{r}15 \\
15 \\
9 \\
3 \\
2 \\
258 \\
85 \\
13 \\
6 \\
2 \\
78 \\
9 \\
11 \\
12\end{array}$ & $\begin{array}{r}0 \\
4 \\
1 \\
0 \\
0 \\
6 \\
30 \\
1 \\
0 \\
2 \\
4 \\
2 \\
3 \\
0\end{array}$ \\
\hline
\end{tabular}

one outbreak each of shigella and cryptosporidiosis. Vaccine preventable diseases were reported in most centres but mostly as isolated cases.

\section{Discussion}

This investigation showed a lack of clear policies regarding communicable disease prevention and control in day care centres in the South West Thames Regional Health Authority. Although guidelines had been prepared in many instances their availability and use varied as did systems of reporting between centres and districts.

Information about the epidemiology and control of communicable disease in day care centres is incomplete. Outbreaks of a number of diseases have been documented, however. ${ }^{12-16}$ An outbreak of cryptosporidiosis was reported in a nursery in the region in 1990 ( $E$ Rang, personal communication). Other studies have reported an incidence rate of diarrhoeal diseases two to three times greater in children attending day care centres than in those staying at home, ${ }^{417}$ particularly diarrhoea caused by giardia and cryptosporidium. ${ }^{18-20}$ Epidemics of subclinical verocytotoxin producing Escherichia coli associated with haemolytic uraemic syndrome have also been reported, ${ }^{16}$ in addition to hepatitis A outbreaks characterised by clusters of clinical hepatitis among staff and parents of children in the day care centres. ${ }^{1321}$

In our survey most of the centres reported episodes of infectious disease in attenders and staff but it is not possible to make epidemiological inferences from these data because the reported cases were not validated and because no data are available about disease incidence in children not attending day care centres. The risk of a particular infectious agent being introduced depends on its prevalence in the community and the number of susceptible subjects in the centre. Once introduced transmission depends partly on the agent, as in mode of spread, infective dose, survival in the environment, and frequency of unrecognised asymptomatic infection, and also on characteristics of the centre such as ages of the children and hygienic aspects of child handling.

The risk of primary $H$ influenzae type b infection has been shown in other studies to be significantly increased in day care attenders, ${ }^{14}$ with an even greater risk in children younger than 2 years and during the first month of attendance. ${ }^{3} H$ influenzae type $\mathrm{b}$ vaccine for children aged two years of age will be introduced in the United Kingdom in late 1992 and this will hopefully reduce the incidence of infections such as otitis media in this age group.

Day care centres are an increasingly important public health setting which could provide opportunities for positive contributions to child health such as ensuring adequate immunisation of children before school age. There was evidence in our study that not all day care centres recommended that parents update their children's immunisation, though nearly half the day care centres funded by social services did arrange for immunisation on site. Any guidelines should emphasise the need to ensure up to date immunisation. Children who have not completed a primary course are likely to be exposed to vaccine preventable diseases on entering day care and also to place their younger siblings who have not been immunised at risk. The national immunisation schedule introduced in May 1990 offers protection to babies from a much younger age ( 2,3 , and 4 months), and parents of children in day care facilities could be targeted to encourage immunisation uptake not only of children attending but of children in the household.

There is a need to address concerns about the transmission of blood borne infections such as hepatitis B and HIV as the study showed that a disturbingly high number of day care centres would exclude a child known to be carrying the hepatitis B virus. Child care providers should be educated about the modes of transmission of blood borne diseases and their prevention. ${ }^{10} \quad 22-24$

Studies in day care centres have shown that young children may shed cytomegalovirus for a number of years after infection and may transmit 
the virus to other children in the centre and to their mothers and child care providers with whom they are in close contact. ${ }^{72-31}$ The incidence of congenital cytomegalovirus infection is three per 1000 live births in the United Kingdom. ${ }^{32}$ Ninety per cent of these children are asymptomatic and in most there are no adverse effects. In the United Kingdom, by the age of 12 months, $20 \%$ of children have acquired cytomegalovirus infection and because most of these will not be recognised excretors it is advisable that all women caring for young children wash their hands carefully after contact with body secretions, especially urine and saliva, to minimise the chance of infection. ${ }^{33}$ Guidelines for day care centres should emphasise the necessity for good personal hygiene to reduce readily transmitted infections such as cytomegalovirus.

Pre-employment screening for tuberculosis was carried out in fewer than half of the day care centres studied and rubella immunisation of female staff recommended in less than one third. Pre-employment screening of staff in day care centres for tuberculosis by the Heaf test has been recommended ${ }^{34}$ and should be included in policies along with guidance to women of childbearing age about the necessity to ensure their own rubella immunity.

This study found a great diversity in the people who day care centres contact over infectious disease matters. There is a need to clarify the appropriate sources of information and the circumstances in which to report communicable diseases.

\section{Recommendations}

(1) Guidelines about the prevention and control of communicable disease should be made available to and should be used by all social services and privately funded day care centres. Good practice with regard to communicable disease control could be a requirement for registration of day care centres by local authorities.

(2) Guidelines should be produced and agreed by consultants in communicable disease control, district immunisation coordinators, community paediatricians, family health service authorities, local authorities, and community nursing staff. It is desirable that the same guidelines are used in a number of contiguous health and local authorities.

(3) Guidelines should include recommendations based on the most up to date knowledge of good practice in personal hygiene, food preparation, immunisation, exclusion criteria for children with communicable disease, and staff health and screening policies.

(4) A clear and efficient method of reporting and seeking expert advice about communicable diseases should be established and agreed by the day care centres, consultants in communicable disease control, and local authorities.

(5) The guidelines should be disseminated widely and updated regularly.
We thank the day care centres and local authority social services departments for their help with this study and Dr David Elliman for his valuable advice.

1 National Children's Bureau. Under Fives Unit. Statistics for under fives and pre-school services. London: NCB, 1986 and 1989.

2 Department of Health. Children's day-care facilities at 31 March 1989-England. London: Department of Health, 1989. Series AF 89/6.

3 Osterholm MT. Invasive bacterial diseases in child day care. Seminars in Pediatric Infectious Diseases 1990;1:222-33.

4 Bartlett AV, Reves RR, Pickering LK. Rotavirus in infants and toddler DCCs. Epidemiology relevant to disease control strategies. I Pediatr 1988;113:435-41.

5 Staat M, Morrow A, Bartlett A. Diarrhoea in children newly enrolled in day-care centres in Houston. Pediatr Infect Dis 7 1991;10:282-6.

6 Klein JO. Infectious disease in day-care. Seminars in Pediatric Infectious Diseases 1986;8:521-5

7 Murphy JR, Baron JC, Brown CK, Ebelhack CL, Bale JF Jr. The occupational risk of $\mathrm{CMV}$ infection among day-care providers. JAMA 1991;265:603-8.

8 Rayashi J, Kashiwagi S, Nomura H, Kaiiyama W, Ikematsu H. Hepatitis B transmission in nursery schools. Am $\mathcal{J}$ Epidemiol $1987,125: 492-8$.

9 Masters MJ, Livingstone A, Cencora V. Hepatitis B. Prevention in primary care. $B M \mathcal{F} 1989 ; 298: 908$

10 Jones D, Rogers MF. HIV infection in child day-care. Seminars in Pediatric Infectious Diseases 1990;1:280-6.

11 Bax M, Hart H, Jenkins SM. Use of services. Child develop ment and child health: the pre-school years. Oxford: Blackwell, 1990:354-77.

12 Pickering L, Bartlett A, Woodward W. Acute infectious diarrhoea among children in day-care. Epidemiol Control Rev Infect Dis 1986;8:539-47.

13 Prikaznikov SA, Balayan NS. Shift in rates and levels of antibody to hepatitis $A$ associated with hepatitis A infections in children's communities. Eur f Epidemiol 1987;3:370-6.

14 Daun $R$. Haemophilus influenzae type $b$ infections in day care attendees. Implications for management. Rev Infect Dis 1986;8:558-67.

15 Brunel P, Taylor-Wiedman J, Lievens A. Varicella in daycare centres. Rev Infect Dis 1986;8:591-8.

16 Milford DV, Taylor CM, Guttridge B, Hall SM, Rowe B, Kleanthous $\mathrm{H}$. Haemolytic uraemic syndrome in the British
Isles 1985-88 associated with verocytotoxin producing Escherichia coli. Part I: clinical and epidemiological aspects. Escherichia coli. Part I: clinical and
Arch Dis Child 1990;65:716-21.

17 Alexander CS, Zinzeleta EM, Mackenzie EJ, Vernon A, Markowitz RK. Acute gastrointestinal illness and childcare arrangements. Am $\mathcal{F}$ Epidemiol 1990;131:124-31.

18 Black RE, Dykes AC, Sinclaire SP, Wells JW. Giardiasis in day-care centres: evidence of person-to-person transmission. Pediatrics 1977;60:486-91.

19 Cryptosporidiosis in children: epidemics and sporadic cases. Ann Pediatr (Paris) 1990;37:381-6.

20 Rauch AM, Van R, Bartlett AV, Pickering LK. Longitudinal study of G lambia infection in DC population. Pediatr Infect Dis ₹ 1990;9:186-9.

21 Hadler SC, McFarland L. Hepatitis in DCC: epidemiology and prevention. Rev Infect Dis 1986;8:548-57.

22 Shapiro CN, McCaig LF, Gensheimer KF, et al. Hepatitis transmission between children in DCCs. Pediatr Infect transmission betwe

23 Shapiro CN, Hadler SC. Significance of hepatitis in children in day-care. Seminars in Pediatric Infectious Diseases 1990;1:

24 World Health Organisation. Guidelines on AIDS and first-aid in the workplace. Geneva: WHO, 1990.

25 Brady M. Cytomegalovirus infections; occupational risk for health professionals. Am F Infect Control 1986;14:197-203.

26 Adler SP. Molecular epidemiology of CMV. Viral transmission among children in a DCC, their parents and caretakers. f Pediatr 1988;112:366-72.

27 Canadian Pediatric Society. Infectious diseases and immunisation committee. CMV infections in DCC: risk to pregnant women. Canadian Medical Association Foumal 1990;142. 547-55.

28 Adler SP. CMV and child care. Evidence for an increased rate among day-care workers. N Engl f Med 1989;321:1290-6.

29 Pass RF, Hutto C, Lyon MD, Cloud G. Increased rate of CMV infection among daycare centre workers. Pediatr CMV infection among day

30 Volpi A, Pica F, Caauletti M, Pana A, Rocchi G. CMV infection in DCCs in Rome. Viral excretion in children and tion in DCCs in Rome. Viral excretion in children and occupationa

31 Tookey P, Peckham C. Does CMV represent an occupational risk? Arch Dis Child 1991;66:1009-10.

32 Preece PM, Pearl KN, Peckham CS. Congenital cytomegalovirus infection. Arch Dis Child 1984;59:1120-6.

33 Committee of infectious disease. Recommendations for children in day care. Elk Grove Village, IL: American Academy of Pediatrics, 1991:67-81.

34 Subcommittee of the Joint Tuberculosis Committee of the British Thoracic Society. Control and prevention of tuberculosis in Britain: an updated code of practice. BMF 1990; 300:995-9. 